\title{
Strategy for introducing antibacterial activity under ambient illumination in titania nanoparticles
}

\author{
Alexander Hsu ${ }^{a}$, Fangzhou Liu ${ }^{\mathrm{a}}$, Yu Hang Leung ${ }^{\mathrm{a}}$, Angel P. Y. Ma ${ }^{\mathrm{b}}$, Aleksandra B. Djurišić*a, \\ Frederick C. C. Leung ${ }^{\mathrm{b}}$ \\ ${ }^{a}$ Department of Physics, University of Hong Kong, Pokfulam Road, Hong Kong \\ ${ }^{\mathrm{b}}$ School of Biological Sciences, University of Hong Kong, Pokfulam Road, Hong Kong
}

\begin{abstract}
Titanium dioxide $\left(\mathrm{TiO}_{2}\right)$ is a wide bandgap $(\sim 3.4 \mathrm{eV})$ semiconductor material which is commonly used as a photocatalyst and antibacterial material. UV illumination with energy similar to the bandgap is often needed to make the material active. It would be favorable for practical applications, if its action can also be activated under ambient. Recently, robust antibacterial action was demonstrated on $\mathrm{ZnO}$ nanoparticles under ambient illumination.

In this study, we demonstrated robust antibacterial activity of $\mathrm{TiO}_{2}$ nanoparticles induced by annealing under ambient illumination. It was found that the antibacterial activity could be significantly changed by tuning the annealing temperatures and using different crucibles containing the nanoparticles. Bacterium Escherichia coli was used as the model organism in the test. It was observed that although no significant antibacterial activity was observed on the starting material (untreated commercial $\mathrm{TiO}_{2}$ nanoparticles), the activity increases significantly if the nanoparticles were annealed above $650{ }^{\circ} \mathrm{C}$ with crucible lined with copper foil. The survival rate of $E$. coli bacteria approaches to zero if the nanoparticles annealing temperature reaches $850{ }^{\circ} \mathrm{C}$. Under optimized conditions, three different titania nanoparticle samples exhibited antibacterial activity under ambient illumination. This work sheds light on the development of ambient-active antibacterial coating and in particular, on the modification of any $\mathrm{TiO}_{2}$ material to become ambient-active with a suitable treatment.
\end{abstract}

*dalek@hku.hk; Tel: +852 2859-7946

Keywords: Antibacterial activity, $\mathrm{TiO}_{2}$, E. coli

\section{INTRODUCTION}

Antibiotic resistance of bacteria is now regarded as one of the major threats to modern human health. World Health Organization (WHO) even states that antibiotic resistance is a growing public health threat of broad concern that threatens the achievements of modern medicine. ${ }^{1}$ Drug-resistant bacteria such as methicilin-resistance Staphylococcus aureus (MRSA), vancomycin-resistance Enterococcus (VRE) have been commonly found in hospitals and nursing homes, which gives extra burden to the health care system. Antibiotic resistance of bacteria is commonly associated with the extensive use of antibiotics. ${ }^{1}$

Recently, researchers have been focusing on developing antimicrobial agents other than the traditional antibiotics. ${ }^{2}$ In particular, metal or metal oxides in nanosized form, i.e. nanoparticles have attracted great interest as a promising candidate. For the former category, it was reported that Ag nanoparticles were effective against different bacterial strains and they were commonly found in different commercial products like cosmetics. ${ }^{3,4}$ Among different metal oxides, $\mathrm{ZnO}^{4-9}$ and $\mathrm{TiO}_{2}{ }^{10,11}$ were the most commonly used antimicrobial agents, although antibacterial activity of $\mathrm{MgO}$ has also been demonstrated. ${ }^{12-13} \mathrm{UV}$ illumination was often needed to facilitate significant antibacterial action in most of the studies. ${ }^{4,5,10,11}$ It would be favorable for practical applications if significant activity can be achieved without UV illumination (i.e. under ambient illumination or even in the dark). Robust antibacterial activity under ambient illumination was demonstrated on $\mathrm{ZnO}$ nanoparticles. ${ }^{7,8}$ On the other hand, reports on "ambient-active" antibacterial activity on $\mathrm{TiO}_{2}$ are scarce. For commercial applications, special concern has to be paid on the ecotoxicity of the material as well due to the fact that the material would eventually end up in the environment. It was reported that both Ag and $\mathrm{ZnO}$ nanoparticles were classified as "extremely toxic" meanwhile $\mathrm{TiO}_{2}$ nanoparticles were regarded as the least toxic among the samples studied. ${ }^{14}$

Oxide-based Materials and Devices VI, edited by Ferechteh H. Teherani, David C. Look, David J. Rogers, Proc. of SPIE Vol. 9364, 93641A · C 2015 SPIE · CCC code: 0277-786X/15/\$18 · doi: 10.1117/12.2078568 
$\mathrm{TiO}_{2}$ is a semiconductor with a wide bandgap $(\sim 3.4 \mathrm{eV})$ and it is commonly used as photocatalyst or antimicrobial agents in commercial applications. Its action is often driven by UV illumination with energy similar to the bandgap. In this study, we demonstrated robust antibacterial activity under ambient illumination on $\mathrm{TiO}_{2}$ nanoparticles induced by annealing. This work provides an idea on the modification of any $\mathrm{TiO}_{2}$ material to become ambient-active with a suitable treatment, which would be helpful for the development of ambient-active antibacterial coatings.

\section{EXPERIMENTAL}

\subsection{Materials}

Three kinds of titania nanoparticles, namely $1-\mathrm{TiO}_{2}, 2-\mathrm{TiO}_{2}$, and $\mathrm{P} 25$ were used. 1- $\mathrm{TiO}_{2}$ (anatase, APS $15 \mathrm{~nm}$, $99 \%$ purity), $2-\mathrm{TiO}_{2}$ (anatase, APS $7 \mathrm{~nm}, 95 \%$ purity), and P25 (Aeroxide ${ }^{\circledR}$ ) were purchased from Nanostructured \& Amorphous Materials, Inc., Division MK Nano of MK Impex Corp., and Degussa (Evonik Industries), respectively. The annealing of the nanoparticles was done using a tube furnace. The nanoparticles were put into a quartz crucible lined with copper foil ( $25 \mu \mathrm{m}$ thick, $>99.99 \%$ purity, MTI Corporation). The crucible was then put into the tube furnace and the system was pumped down to $\sim 10^{-2}$ Torr. The system was purged with Ar gas for 10 minutes to remove the oxygen present inside the tube. The nanoparticles were annealed at different temperature at a pressure of $\sim 10^{-2}$ Torr, followed by cooling down naturally.

\subsection{Antibacterial activity experiments}

A Gram-negative bacterium Escherichia coli XL1-Blue (Stratagene, USA) was used as the model organism for antibacterial activity experiments. The bacteria were cultured in Luria-Bertani (LB) broth (Affymetrix/USB) at $37^{\circ} \mathrm{C}$. $0.9 \% \mathrm{w} / \mathrm{v} \mathrm{NaCl}$ aqueous solution was used as the suspension medium for antibacterial activity experiments as it was reported that LB broth was not a suitable medium for photocatalytic antibacterial experiments. ${ }^{15}$ For the preparation of sample plates for testing, different nanoparticle suspensions $(100 \mu \mathrm{g} / \mathrm{ml})$ were drop-cast on glass substrates, followed by drying in ambient overnight. For the antibacterial activity experiments, $500 \mu \mathrm{l}$ of bacteria suspension $\left(10^{6} \mathrm{CFU} / \mathrm{ml}\right)$ was dropped onto the sample plates and illuminated under ambient laboratory lighting for 4 hours. Serial dilution was performed and the dilution was pipetted on LB agar (Affymetrix/USB) plates. The plates were incubated at $37{ }^{\circ} \mathrm{C}$ for $\sim 16$ hours and the formation of colonies was observed.

For the investigation of the interaction between the nanoparticles and bacterial cells, scanning electron microscopy (SEM) was on the bacterial cells was performed. After the exposure to nanoparticles, the bacterial cells were collected by centrifugation and fixed in $2.5 \%$ glutaraldehyde in cacodylate buffer $(0.1 \mathrm{M}$ sodium cacodylate- $\mathrm{HCl}$ buffer, $\mathrm{pH} 7.4)$ at $4^{\circ} \mathrm{C}$ overnight. The cells were then collected with a membrane $(0.8 \mu \mathrm{m}$ pore size, Millipore). The cells were washed with cacodylate buffer and serially dehydrated with ethanol, followed by drying with critical point drying method. Finally, a thin layer of Au was coated on the specimens, and SEM was performed using LEO 1530 FEG SEM.

\section{RESULTS AND DISCUSSIONS}

Annealing was performed at various temperatures $\left(450,650,750\right.$, and $\left.850{ }^{\circ} \mathrm{C}\right)$. The nanoparticles before and after annealing were shown on Figure 1. The color turned from white to light grey after the annealing, suggesting that the annealed nanoparticles may be able to absorb visible light. Table 1 and Figure 1 show the antibacterial activity test results for $1-\mathrm{TiO}_{2}$ nanoparticles. It can be observed that the antibacterial activity increases with annealing temperature of the nanoparticles. The survival rate approaches to zero if the nanoparticles annealing temperature reaches $850{ }^{\circ} \mathrm{C}$.

Since it was shown that for $\mathrm{ZnO}$ very different antibacterial activity can be observed for different samples with and without surface modification, ${ }^{8,9}$ it is necessary to investigate whether other titania samples would behave the same after the annealing process. Two other $\mathrm{TiO}_{2}$ nanoparticles, 2- $\mathrm{TiO}_{2}$ and $\mathrm{P} 25$ were tested. These samples were manufactured by two different companies. Since material properties are highly dependent to the synthesis method, the samples would very likely have significantly different properties as they were likely produced by different methods. The two samples were annealed at elevated temperatures with the same conditions and the antibacterial activity test results are shown on Table 2 and Figure 2. Similar to $1-\mathrm{TiO}_{2}$, both samples exhibited increased antibacterial activity after 
annealing at temperatures of $650{ }^{\circ} \mathrm{C}$ or above, even though the samples had significantly different activities under ambient illumination in their unannealed form. This suggests that such annealing process may be able to turn any titania samples to become ambient-active.

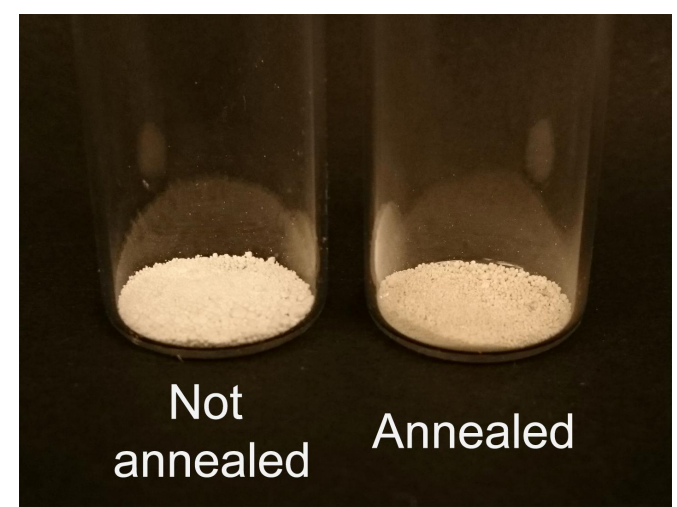

Figure 1. Photos of $1-\mathrm{TiO}_{2}$ nanoparticles a) not annealed and b) annealed at $750{ }^{\circ} \mathrm{C}$.

Table 1. Number of bacteria colonies for bacteria exposed to control (i.e. blank glass plate) and plates coated with $1-\mathrm{TiO}_{2}$ nanoparticles annealed with different temperatures. The exposure time is 4 hours.

\begin{tabular}{ccc}
\hline Sample & Colonies count $($ Mean \pm S. D.) & Survival rate (\%) \\
\hline Control & $1374,1324,1154(1284 \pm 115)$ & $\mathbf{1 0 0 . 0}$ \\
Not annealed & $379,414,402(398 \pm 18)$ & $\mathbf{3 1 . 0}$ \\
$450{ }^{\circ} \mathrm{C}$ annealed & $321,339,350(337 \pm 15)$ & $\mathbf{2 6 . 2}$ \\
$650{ }^{\circ} \mathrm{C}$ annealed & $138,162,175(158 \pm 19)$ & $\mathbf{1 2 . 3}$ \\
$750^{\circ} \mathrm{C}$ annealed & $110,161,156(142 \pm 28)$ & $\mathbf{1 1 . 1}$ \\
$850^{\circ} \mathrm{C}$ annealed & $0,0,0(0 \pm 0)$ & $\mathbf{0 . 0}$ \\
\hline
\end{tabular}

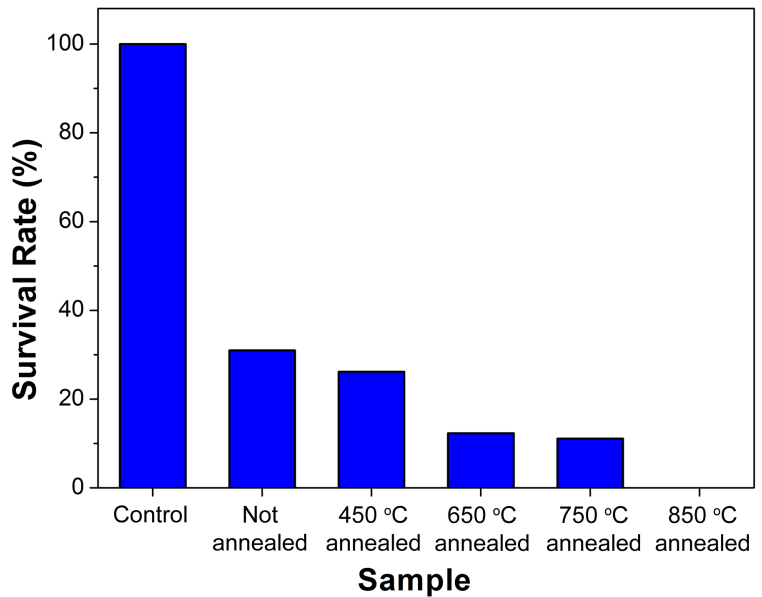

Figure 2. Survival rate of E. coli bacteria after the exposure to $1-\mathrm{TiO}_{2}$ nanoparticles annealed at different temperatures. 
Table 2. Number of bacteria colonies for bacteria exposed to control (i.e. blank glass plate) and plates coated with three different $\mathrm{TiO}_{2}$ nanoparticles annealed with different temperatures. The exposure time is 4 hours.

\begin{tabular}{cccc}
\hline Sample & $\begin{array}{c}\text { Annealing } \\
\text { temperature } \\
\left({ }^{\circ} \mathrm{C}\right)\end{array}$ & Colonies count $($ Mean \pm S. D. $)$ & $\begin{array}{c}\text { Survival rate } \\
\text { (\%) }\end{array}$ \\
\hline Control & N/A & $401,389,402(397 \pm 7)$ & $\mathbf{1 0 0 . 0}$ \\
\hline \multirow{2}{*}{$1-\mathrm{TiO}_{2}$} & Not annealed & $144,132,142(139 \pm 6)$ & $\mathbf{3 5 . 1}$ \\
& 650 & $31,31,29(30 \pm 1)$ & $\mathbf{7 . 6}$ \\
& 850 & $0,0,0(0 \pm 0)$ & $\mathbf{0 . 0}$ \\
\hline $2-\mathrm{TiO}_{2}$ & Not annealed & $61,66,53(60 \pm 7)$ & $\mathbf{1 5 . 1}$ \\
& 650 & $19,32,24(25 \pm 7)$ & $\mathbf{6 . 3}$ \\
$\mathrm{P}^{25}$ & 850 & $0,0,0(0 \pm 0)$ & $\mathbf{0 . 0}$ \\
\hline & Not annealed & $282,245,258(262 \pm 19)$ & $\mathbf{6 5 . 9}$ \\
& 650 & $3,8,3(5 \pm 3)$ & $\mathbf{1 . 2}$ \\
\hline
\end{tabular}

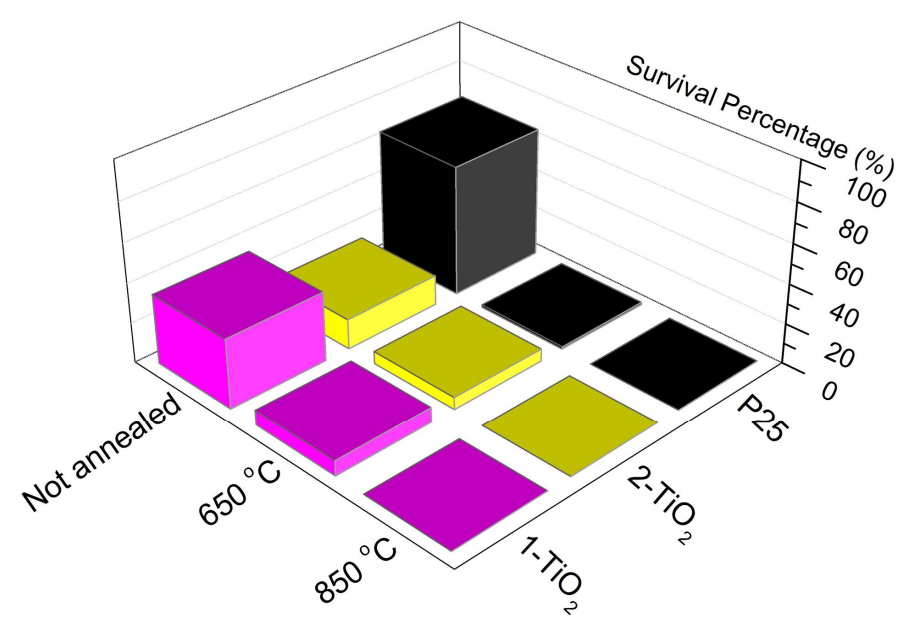

Figure 3. Survival rate of E. coli bacteria after the exposure to three different $\mathrm{TiO}_{2}$ nanoparticles annealed at different temperatures.

Figure 4 shows the SEM photos of the E. coli bacterial cells after exposed to $1-\mathrm{TiO}_{2}$ nanoparticles annealed (Figure 4c-4f) and not annealed (Figure 4b). Ruptures and holes are observed on the cells exposed to nanoparticles, suggesting that cell deaths are likely caused by cell membrane damages. Reactive oxygen species (ROS) were commonly reported to be the cause of cell membrane damages, ${ }^{16,17}$ although other mechanisms like interaction between nanoparticles and cell membranes without the involvement of ROS were also reported. ${ }^{13,18}$ Further works such as ROS detection and analysis on the cell membranes such as FTIR spectroscopy were needed to clarify the cell death mechanism. 


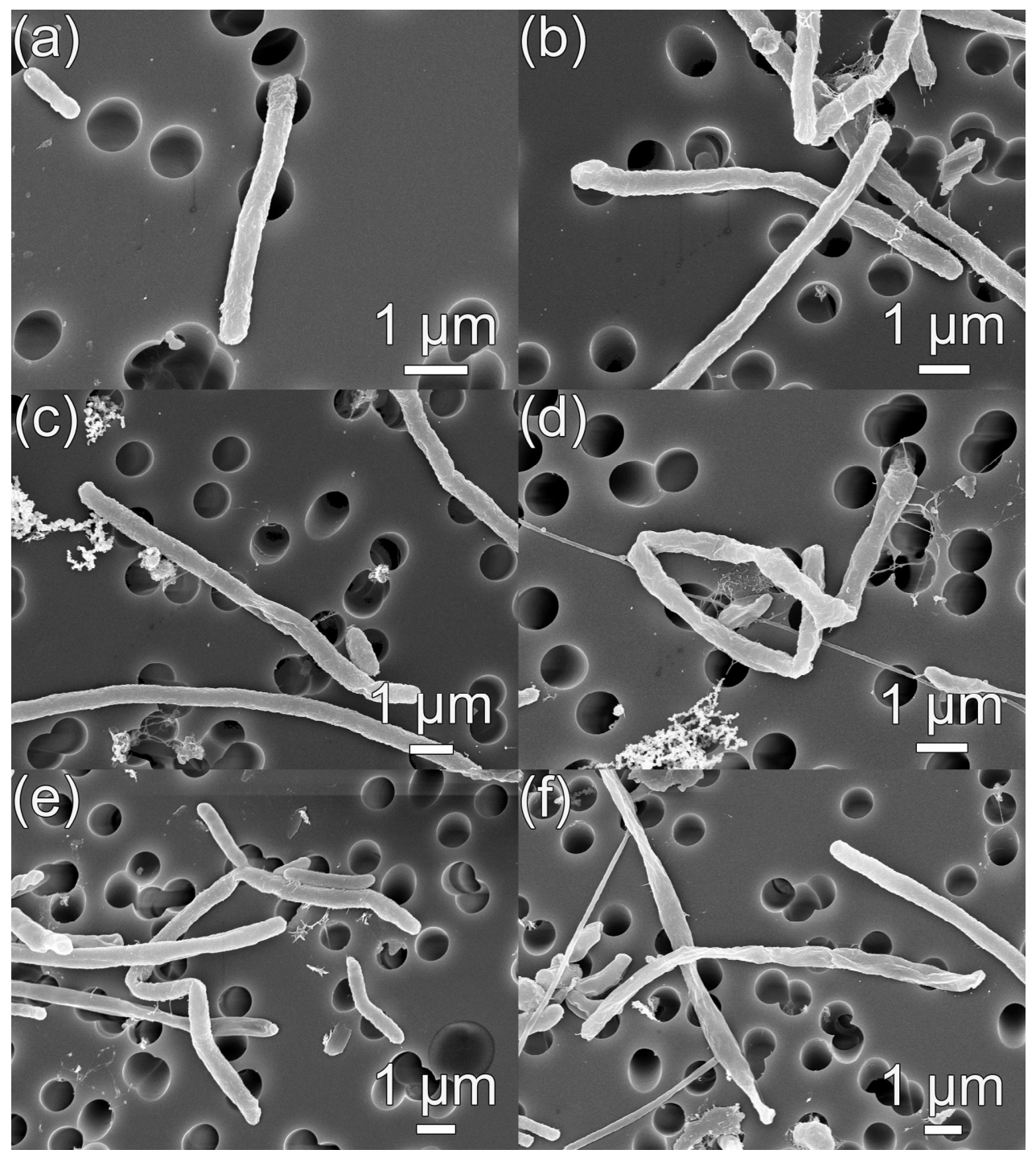

Figure 4. Representative SEM photos of the E. coli bacteria. a) control; b) exposed to $1-\mathrm{TiO}_{2}$ nanoparticles; exposed to 1$\mathrm{TiO}_{2}$ nanoparticles annealed at c) $450{ }^{\circ} \mathrm{C}$, d) $650{ }^{\circ} \mathrm{C}$, e) $750{ }^{\circ} \mathrm{C}$, and f) $850{ }^{\circ} \mathrm{C}$.

\section{CONCLUSION}

In this study, we demonstrated a possible strategy to introduce ambient-active antibacterial activity in titania nanoparticles. Even though no significant antibacterial activity was observed in the as-purchased titania nanoparticles, the activity increases if the nanoparticles were annealed above $650{ }^{\circ} \mathrm{C}$ with crucible lined with copper foil. Three titania samples from different manufacturers were tested. The outcome was the same regardless that the samples had different activities under ambient illumination in their original form. This work sheds light on the development of ambient-active antibacterial coating and in particular, on the modification of any titania material to become ambient-active with a suitable treatment.

\section{ACKNOWLEDGMENT}

This work is partly supported by the University Development Fund, Strategic Research Theme, and Small Project Grant administered by the University of Hong Kong. 


\section{REFERENCES}

[1] WHO, Antimicrobial resistance, http://www.who.int/mediacentre/factsheets/fs194/en/.

[2] Huh, A. J. and Kwon, Y. J., "'Nanoantibiotics": A new paradigm for treating infectious diseases using nanomaterials in the antibiotics resistant era," J. Controlled Release 156(2), 128-145 (2011).

[3] Samberg, M. E., Orndorff, P. E. and Monteiro-Riviere, N. A., "Antibacterial efficacy of silver nanoparticles of different sizes, surface conditions and synthesis methods," Nanotoxicology 5(2), 244-253 (2011).

[4] Li, Q. L., Mahendra, S., Lyon, D. Y., Brunet, L., Liga, M. V., Li, D. and Alvarez P. J. J., "Antimicrobial nanomaterials for water disinfection and microbial control: Potential applications and implications," Water Res. 42(18), 4591-4602 (2008).

[5] Brayner, R., Ferrari-Iliou, R., Brivois, N., Djediat, S., Benedetti, M. F. and Fiévet, F., "Toxicological Impact Studies Based on Escherichia coli Bacteria in Ultrafine ZnO Nanoparticles Colloidal Medium," Nano Lett. 6(4), 866-870 (2006).

[6] Tam, K. H., Djurišić, A. B., Chan, C. M. N., Xi, Y. Y., Tse, C. W., Leung, Y. H., Chan, W. K., Leung, F. C. C. and $\mathrm{Au}, \mathrm{D}$. W. T., "Antibacterial activity of $\mathrm{ZnO}$ nanorods prepared by a hydrothermal method," Thin Solid Films 516(18), 6167-6174 (2008).

[7] Leung, Y. H., Chan. C. M. N., Ng, A. M. C., Chan, H. T., Chiang, M. W. L., Djurišić, A. B., Ng, Y. H., Jim, W. Y., Guo, M. Y., Leung, F. C. C., Chan, W. K. and Au, D. T. W., "Antibacterial activity of ZnO nanoparticles with a modified surface under ambient illumination," Nanotechnology 23(47), 475703 (2012).

[8] Ng, Y. H., Leung, Y. H., Liu, F. Z., Ng, A. M. C., Gao, M. H., Chan, C. M. N., Djurišić, A. B., Leung, F. C. C. and Chan, W. K., "Antibacterial activity of $\mathrm{ZnO}$ nanoparticles under ambient illumination - The effect of nanoparticle properties," Thin Solid Films 542, 368-372 (2013).

[9] Hsu, A., Liu, F. Z., Leung, Y. H., Ma, A. P. Y., Djurišić, A. B., Leung, F. C. C., Chan, W. K. and Lee, H. K., "Is the effect of surface modifying molecules on antibacterial activity universal for a given material?," Nanoscale 6(17), 10323-10331 (2014).

[10] Wist, J., Sanabria, J., Dierolf, C., Torres, W. and Pulgarin, C., "Evaluation of photocatalytic disinfection of crude water for drinking-water production," J. Photochem. Photobiol., A 147(3), 241-246 (2002).

[11]Foster, H. A., Ditta, I. B., Varghese, S. and Steele, A., "Photocatalytic disinfection using titanium dioxide: spectrum and mechanism of antimicrobial activity," Appl. Microbiol. Biotechnol. 90(6), 1847-1868 (2011).

[12] Sawai, J., Kojima, H., Igarashi, H., Hashimoto, A., Shoji, S., Sawaki, T., Hakoda, A., Kawada, E., Kokugan, T. and Shimizu, M., "Antibacterial characteristics of magnesium oxide powder," World J. Microbiol. Biotechnol. 16(2), 187-194 (2000).

[13] Leung, Y. H., Ng, A. M. C., Xu, X. Y., Shen, Z. Y., Gethings, L. A., Wong, M. T., Chan, C. M. N., Guo, M. Y., Ng, Y. H., Djurišić, A. B., Lee, P. K. H., Chan, W. K., Yu, L. H., Phillips, D. L., Ma, A. P. Y. and Leung, F. C. C., "Mechanisms of Antibacterial Activity of MgO: Non-ROS Mediated Toxicity of MgO Nanoparticles Towards Escherichia coli," Small 10(6), 1171-1183 (2014).

[14] Kahru, A. and Dubourguier, H.-C., "From ecotoxicology to nanoecotoxicology," Toxicology 269(2-3), 105-119 (2010).

[15] Cushnie, T. P. T., Robertson, P. K. J., Officer, S., Pollard, P. M., McCullagh, C. and Robertson, J. M. C., "Variables to be considered when assessing the photocatalytic destruction of bacterial pathogens," Chemosphere 74(10), 1374-1378 (2009).

[16] Kiwi, J. and Nadtochenko, V., "Evidence for the Mechanism of Photocatalytic Degradation of the Bacterial Wall Membrane at the $\mathrm{TiO}_{2}$ interface by ATR-FTIR and Laser Kinetic Spectroscopy," Langmuir 21(10), 46314641 (2005).

[17] Nadtochenko, V. A., Rincon, A. G., Stanca, S. E. and Kiwi, J., "Dynamics of E. coli membrane cell peroxidation during $\mathrm{TiO}_{2}$ photocatalysis studied by ATR-FTIR spectroscopy and AFM microscopy," J. Photochem. Photobiol., A 169(2), 131-137 (2005).

[18] Jiang, W., Yang, K., Vachet, R. W. and Xing, B. S., "Interaction Between Oxide Nanoparticles and Biomolecules of the Bacterial Cell Envelope As Examined by Infrared Spectroscopy," Langmuir 26(23), 1807118077 (2010). 